\title{
Efficacy of bioagents and plant extract against Alternaria porri causing purple blotch of onion
}

\author{
P.R. BRAHMANE*, B.P. DANDNAIK AND P.B. ABHANG \\ Department of Plant Pathology, College of Agriculture (V.N.M.A.U.), LATUR (M.S.) INDIA
}

\section{ARITCLE INFO}

Received : 01.04 .2015

Revised : 05.08 .2015

Accepted : 20.08.2015

\section{KEY WORDS :}

Onion, Purple blotch of onion, Bioagents, Plant extract

*Corresponding author:

Email: priyankabrahmane29@gmail.com

\begin{abstract}
The bioagent T.harzarium was found most effective in controlling the pathogen. Lowest disease severity $(37.67 \%)$ was recorded in the spray treatment of T.harzarium.It was followed by T. viride and P. fluorescens, B. subtilis. Among the plant extract 5 per cent neem seed kernel extract gave maximum control of pathogen i.e. 44.24 per cent over control, followed by Followed by Mentha arvensis, Allium sativum, Zingiber officinale, Vitex negundo.The fungicide Mancozeb was at found at par with extract of NSK and Mentha arvensis.
\end{abstract}

How to view point the article : Brahmane, P.R., Dandnaik, B.P. and Abhang, P.B. (2015). Efficacy of bioagents and plant extract against Alternaria porri causing purple blotch of onion. Internat. J. Plant Protec., 8(2) : 265-269. 